\title{
Variation in aeolian environments recorded by the particle size distribution of lacustrine sediments in Ebinur Lake, northwest China
}

\author{
Long $\mathrm{Ma}^{1^{*}}$, Jinglu $\mathrm{Wu}^{2^{*}}$ and Jilili Abuduwaili ${ }^{1}$
}

\begin{abstract}
Particle size analysis of lacustrine core sediments and atmospheric natural dust were conducted in the drainage area of Ebinur Lake in arid northwest China. Using a combination of ${ }^{137} \mathrm{Cs}$ and ${ }^{210} \mathrm{~Pb}$ dating, a continuous record of aeolian transportation to the lake sediments and related factors over about the past 150 years was analyzed. Factor analysis revealed the particle-size distributions of riverine and aeolian sediments composed of the terrigenous materials of the lake deposits. Compared with the grain-size distributions of natural dust samples, the results showed that the coarser particle size fraction of lake sediments was mainly derived from the sediments that had experienced aeolian transport to the drainage surface, and the finer sediments came from hydraulic inputs. Then, the method of variations in particle-size standard deviation was used to extract the grain size intervals with the highest variability along a sedimentary sequence. The coarser grain-size populations dominated the variation patterns of the sedimentary sequence. During the last 150 years, strong intensity aeolian transportation occurred during three periods, 1915-1935, 1965-1975 and since the beginning of the 2000s. The climate was dry around 1910s-1930s in this region associated with the appropriate dynamic condition, which provided the enhanced source materials and wind power for the aeolian dust transport. Since 1950s, the climate controlled the foundation of aeolian dust transport, and the aeolian dust transport won't be increased under the humid climate.
\end{abstract}

Keywords: Aeolian transportation, China, Ebinur Lake, Lake sediment, Particle size

\section{Background}

Long-term temporal perspectives provide an important part of understanding contemporary environmental change and related processes (Anderson 1995). Analyzing the environmental evolution, mutation events and factors that influenced them in the historical period will also provide a reference for future regional eco-environmental protection. Dust is recognized as an important

\footnotetext{
*Correspondence: malong@ms.xjb.ac.cn; w.jinglu@niglas.ac.cn ${ }^{1}$ State Key Laboratory of Desert and Oasis Ecology, Xinjiang Institute of Ecology and Geography, Chinese Academy of Sciences, Urumqi 830011, China

${ }^{2}$ State Key Laboratory of Lake Science and Environment, Nanjing Institute of Geography and Limnology, Chinese Academy of Sciences, Nanjing 210008, China

Full list of author information is available at the end of the article
}

physical and chemical flux within ecosystems (Lawrence and Neff 2009; McTainsh and Strong 2007), and dust storms are prevalent in arid regions (Xu et al. 2006). Currently, both the characteristics of modern dust storms (Wake et al. 1994; Wang et al. 2004) and the mechanisms that control them (Wang et al. 2006) have been extensively studied. However, the changes of dust storms in the historical period and the factors influencing that change also need to be analyzed under the context of human activity and natural factors.

Lacustrine sediments have the composition of autochthonous and allochthonous materials that provide information about past environmental change in the surrounding watersheds (Last and Smol 2006; Overpeck et al. 1997). Particle-size of terrigenous materials in lake sediments have been widely used as environmental 
indicators in sedimentary researches (Peng et al. 2005; Qiang et al. 2007; Zhong et al. 2010). In arid regions, variations in sediment transport, such as hydraulic and aeolian transport, cause the distribution of grain-size to be polymodal and represent different transport and depositional processes (Sun et al. 2002). Some researchers used Weibull (Sun et al. 2002) and unimodal lognormal distributions (Qin et al. 2005; Xiao et al. 2009), respectively, to decompose multimodal grain-size distributions. End-member mixing analysis also used to extract environmentally sensitive populations of particle size data (Weltje 1997). Boulay et al. (2003) used the variations of standard deviation to obtain the grain size intervals with the highest variability along a sedimentary sequence. These methods provided powerful tools for decomposition of particle-size distributions that inferred the different transport and depositional processes.

In this study, we focused on the distribution of particle size in Ebinur Lake sediments. Our objectives were: (1) to identify the history of aeolian transport over the past $\sim 150$ years, and (2) to conduct a regional comparison and reveal the possible factors influencing the variation in aeolian transport.

\section{Methods}

\section{Sample collection and analysis}

Ebinur Lake, closed lake in northwestern China, lies near the border to Kazakhstan and at the southeast end of the Dzungaria Gate. The catchment of Ebinur Lake drains an area of $50,321 \mathrm{~km}^{2}$. The lake water depth averages $1.2 \mathrm{~m}$ with a maximum $3.5 \mathrm{~m}$ (Wu et al. 2009). A 50-cm short sedimentary core (AB01) was obtained from north-central part of Ebinur Lake using a piston-percussion corer with a 60-mm inner diameter perspex tubes in 2011 (Fig. 1). In this study, all sediments samples were sectioned into $1 \mathrm{~cm}$ intervals. The subsamples were kept in plastic bags and stored at $4{ }^{\circ} \mathrm{C}$ before being analyzed.

Passive dustfall collectors were used to trap aeolian dust samples in the Ebinur drainage area (Liu et al. 2011). Traps consisted of polyethylene cylinders with a diameter of $15 \mathrm{~cm}$ and depth of $30 \mathrm{~cm}$ mounted vertically on posts about $3 \mathrm{~m}$ above the ground and no specific trapping mechanisms. Dustfalls was brushed off from the collectors into prepared clean small bags. Subsamples for grain-size distribution measurements were extracted by a quartering method that reduces a sample by successively mixing, dividing into quarters and keeping two opposite quarters of the sample.

\section{Laboratory analysis}

${ }^{210} \mathrm{~Pb}$ and ${ }^{137} \mathrm{Cs}$ were detected by direct gamma spectrometry using an Ortec HPGe GWL series, well-type, coaxial, low background and intrinsic germanium detector (Wu et al. 2009). Grain-size distribution measurements of all samples from lake sediments and aeolian dusts were carried out on a Malvern Mastersizer 2000 equipped with a Hydro $2000 \mathrm{MU}$ dispersion unit with a measurement range of $0.02-2000 \mu \mathrm{m}$. Prior to particle size analysis, with $10-20 \mathrm{ml}$ of $30 \% \mathrm{H}_{2} \mathrm{O}_{2}$, samples were pretreated to remove organic matter, and to remove carbonates with $10 \mathrm{ml}$ of $10 \% \mathrm{HCl}$. Deionized water (2 l) was added and $24 \mathrm{~h}$ standing to remove the acid. Finally, the sample residue was treated with $10 \mathrm{ml}$ of $0.05 \mathrm{M}$ $\left(\mathrm{NaPO}_{3}\right)_{6}$, and then, placed on an ultrasonic vibrator for $10 \mathrm{~min}$ sonication to facilitate dispersion before particle size analysis. A Malvern Mastersizer-2000 analyzer equipped with a Hydro 2000 MU dispersion unit, from Malvern Instruments Ltd. (Malvern, Worcestershire, UK) was used to conduct the particle size. The pump speed was set at $2000 \mathrm{rpm}$, and the refractive index and absorption parameter were 1.520 and 0.1 , respectively. The sample was added till obscuration range was within 10-20\%. The Mastersizer 2000 automatically yields the percentages of the related size fractions of a sample with a relative error scale of less than $1 \%$.

\section{Results}

Figure 2a shows the distribution of ${ }^{210} \mathrm{~Pb}$ and ${ }^{137} \mathrm{Cs}$ activities. The unsupported ${ }^{210} \mathrm{~Pb}$ activity $\left({ }^{210} \mathrm{~Pb}_{\mathrm{ex}}\right.$, ${ }^{210} \mathrm{~Pb}$ ex $=$ total $\left.{ }^{210} \mathrm{~Pb}-{ }^{226} \mathrm{Ra}\right)$. The ${ }^{210} \mathrm{~Pb}$ ex decreased from $250 \mathrm{~Bq} / \mathrm{kg}$ at surface to zero at nearly $49 \mathrm{~cm}$ (Fig. 2a). A constant rate of supply model was used to calculate the date for each core sample (Appleby 2001). The beginning of ${ }^{137} \mathrm{Cs}$ activity was appointed 1954 and the peak value was the 1963 fallout maximum from atmospheric testing of nuclear weapons (Pennington et al. 1973), which was consistent with the ${ }^{210} \mathrm{~Pb}$ chronology. Figure $2 \mathrm{~b}$ provides a plot of the sedimentary data versus geologic age.

Sediment particle size fractions of $(<4 \mu \mathrm{m}),(4-16 \mu \mathrm{m})$, $(16-32 \mu \mathrm{m}),(32-64 \mu \mathrm{m})$ and $(>64 \mu \mathrm{m})$ were generally about $31.1,47.5,15.2,5.1,1.1 \%$, respectively. Figure $2 b$ presents values of particle size plotted versus depth, which show strong variations in particle size occur at a depth of about $30 \mathrm{~cm}$. Long-term fluctuations of the $<4-\mu \mathrm{m}$ size components are correlated to those of the 4-16 $\mu \mathrm{m}$ ones, and the others are correlated with each other. The particle size frequency distribution curves for dust samples in the Ebinur drainage area span a wide range of $0.3-700 \mu \mathrm{m}$, within the modal particle size of 10-100 $\mu \mathrm{m}$ (Fig. 3).

\section{Discussion}

Factor analysis was applied as a useful method for source apportionment and identification of the influences on 

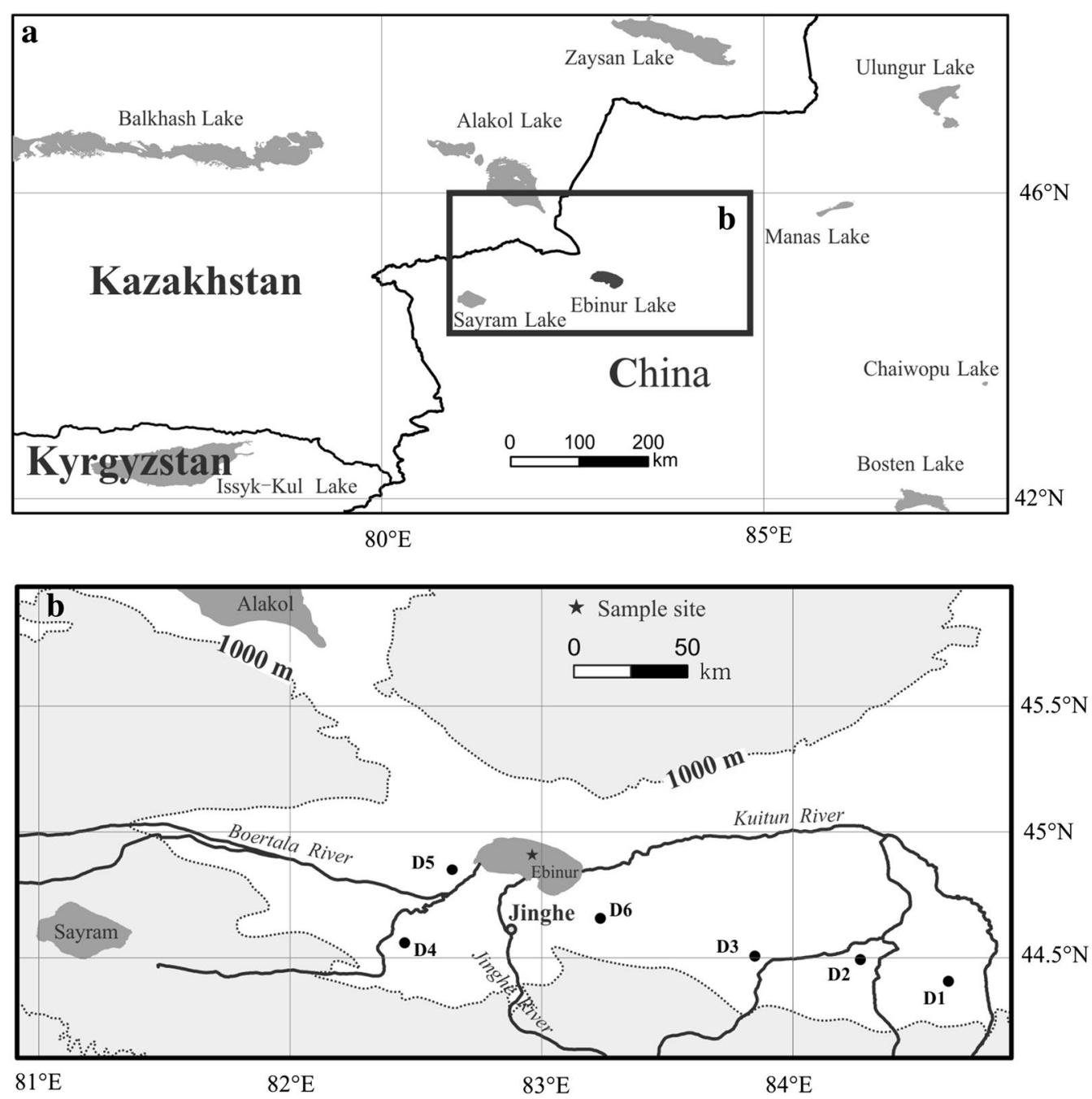

Fig. 1 Vicinity map of the regions of Ebinur Lake (a), and the sites of core sediment and dust samples (b)

sedimentary environments (Christensen and Bzdusek 2005; Sofowote et al. 2008). Factor analysis was conducted by SPSS software with variables of the particle size frequency distribution of different samples (Fig. 4a). The first (F1) and second (F2) factor accounted for 61.6 and $36.5 \%$ of total variance, respectively. The factorscore (Fig. 4b) and factor-loading (Fig. 4c) matrices can be interpreted in terms of source profiles and contributions, respectively. The coarse particle size fraction (F2) was combined with the moderate-to-coarse grain sediments with a modal diameter of $52 \mu \mathrm{m}$. The modal diameter of the coarse fraction is consistent with dust samples from Ebinur drainage area, which showed that the large particle fraction of lake sediments was mainly from the drainage surface sediments.

The variation of standard deviation method (Boulay et al. 2003; Sun et al. 2003) was used to identify the grain size intervals with the highest variability along a sedimentary sequence. From Fig. 4d, we can identify the intervals with the highest value of standard deviation. Figure $4 \mathrm{~d}$ displays standard deviation values versus particle size classes of the collected sediments. Two peaks are observed at particle size intervals of 5-9 (C1) and 25-45- $\mu \mathrm{m}(\mathrm{C} 2)$, respectively. Each of two 

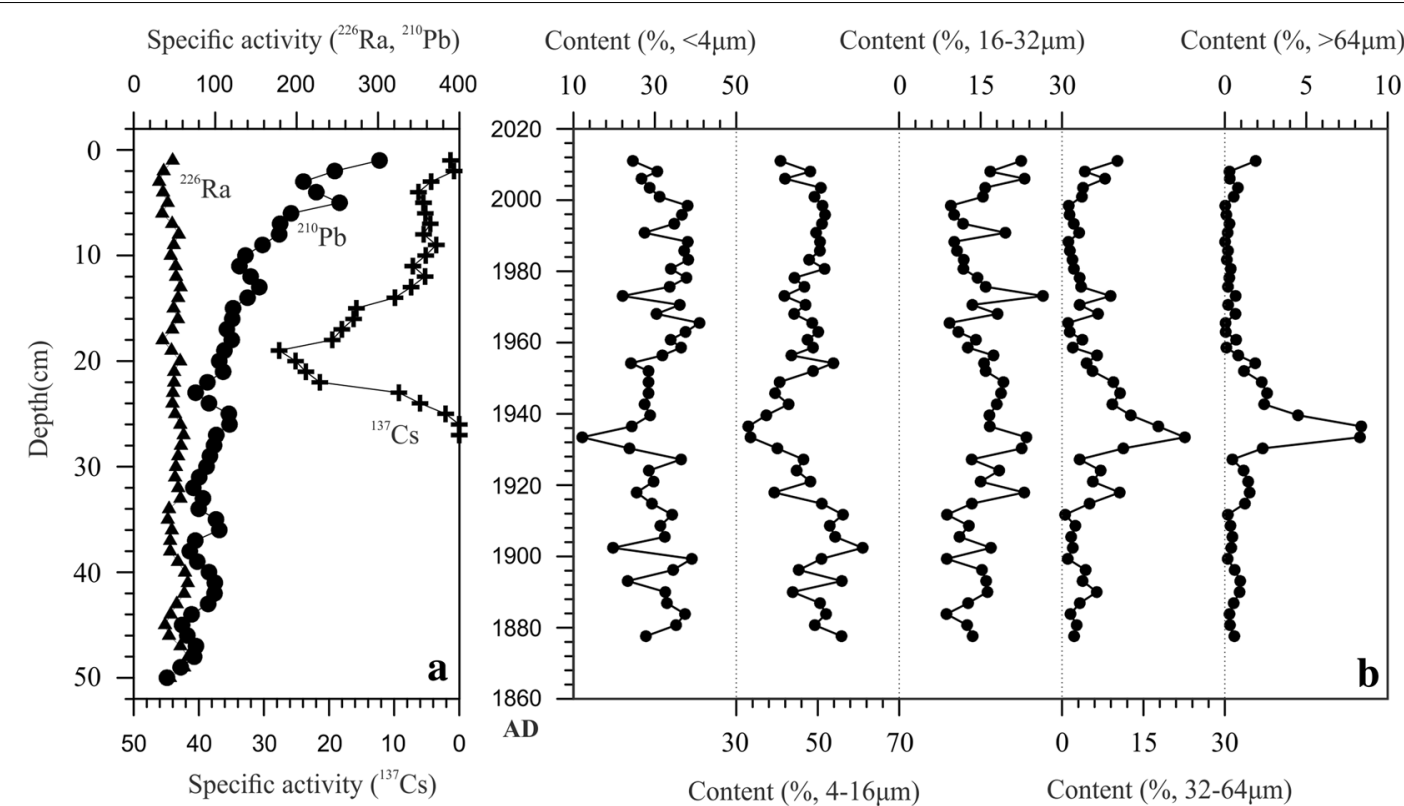

Fig. 2 The specific activity of ${ }^{137} \mathrm{Cs}$, total ${ }^{210} \mathrm{~Pb}$ and ${ }^{226} \mathrm{Ra}$ versus depth in sediment cores of Ebinur Lake $(\mathbf{a})$ and the related particle size distribution of the sediment cores $(\mathbf{b})$

components represents a subpopulation with the highest variability along the sedimentary sequence (Fig. 5). The intermediate fraction of $13-17-\mu \mathrm{m}$ (C3) had low standard deviation values, which indicated unconspicuous variation through time (Fig. 5). The content fluctuation of $\mathrm{C} 1$ is inversely correlated to those of $\mathrm{C} 2$, however, the fluctuation of the coarse population (F2) distribution are correlated to the mean size distribution, which shows that the coarse grain-size population mainly influences the entire variation of the sedimentary sequence. Based on the factor analysis, the coarse environmental population was from aeolian terrigenous materials. At depths of 45, 11 and $4 \mathrm{~cm}$ (Fig. 5) corresponding to 1915-1935, 1965-1975 and since the beginning of the 2000s, the proportions of the two populations display marked variability that be attributed to three environmental events.

From ca. 1910 to the 1930s, regional climate was generally dry inferred from organic matter and its stable isotope $\left({ }^{13} \mathrm{C}\right)$ in the lacustrine records of Chaiwopu Lake (Ma et al. 2013), the record of Palmer Drought Severity Index (PDSI) in the central Tianshan Mountain area (Li et al. 2006), and the tree-ring data in northern China (Liang et al. 2006). From 1950s, Modern weather station records can provide us the instrumental data. To analyze the modern humidity changes in the Ebinur drainage area, relative humidity records from the Jinghe
Meteorological Station in this region (China Meteorological Data Sharing Service System, http://data.cma.cn; Fig. 6). Due to the differences in time resolution between the data of relative humidity and $\mathrm{C} 2$ contents, the average data were recalculated with 5 -year intervals. The contents of $\mathrm{C} 2$ reflected the intensity of aeolian transport are negatively correlated with data of the regional humidity in Jinghe with 5-year time resolution $(\mathrm{r}=-0.613$, $\mathrm{p}<0.05)$. That dry climate provided abundant material basis for aeolian dust transports.

Abundant sand and dust materials are the foundation for aeolian dust transport; however, Wind provides a dynamic condition (Zhang et al. 2005). Some researchers have shown that climate change in Xinjiang has a significant teleconnection with the North Atlantic Oscillation (NAO) (Chen et al. 2006), Siberia High (Li et al. 2012a), and the Arctic Oscillation (AO) (Li et al. 2012b). In the period of the 1910s-1930s, significant variation in the in NAO, AO (Hurrell et al. 2003) and SH indices appeared (D'Arrigo et al. 2005; Jeong et al. 2011), which inferred that the climate in our study area experienced a severe change induced by the instability of the atmosphere. The wind is one of the driving forces for dust transportation (Liu et al. 2004). The AO, shown in Fig. 6 (Li and Wang 2003), reflects the tendency for the zonal winds at $35^{\circ}$ and $55^{\circ} \mathrm{N}$ (Neff et al. 2008). During the high index state of the AO, surface pressure of the polar region is low, 

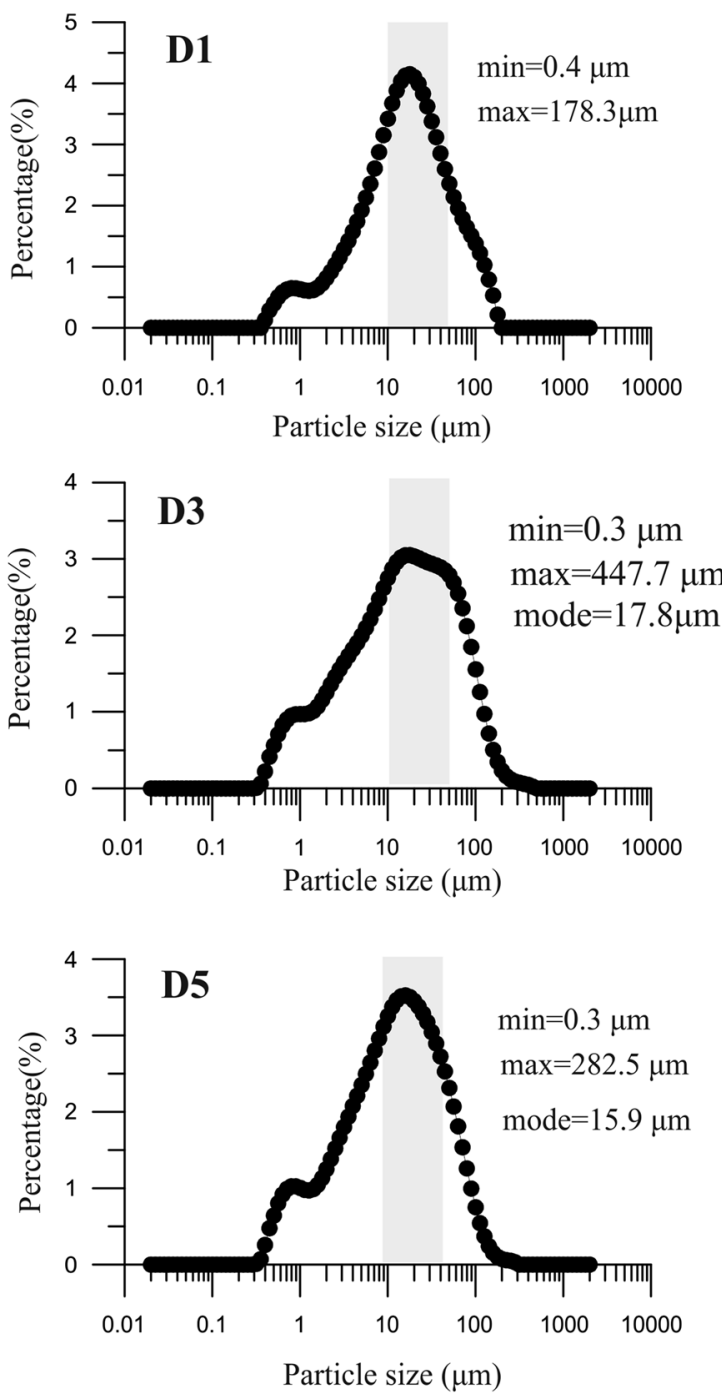
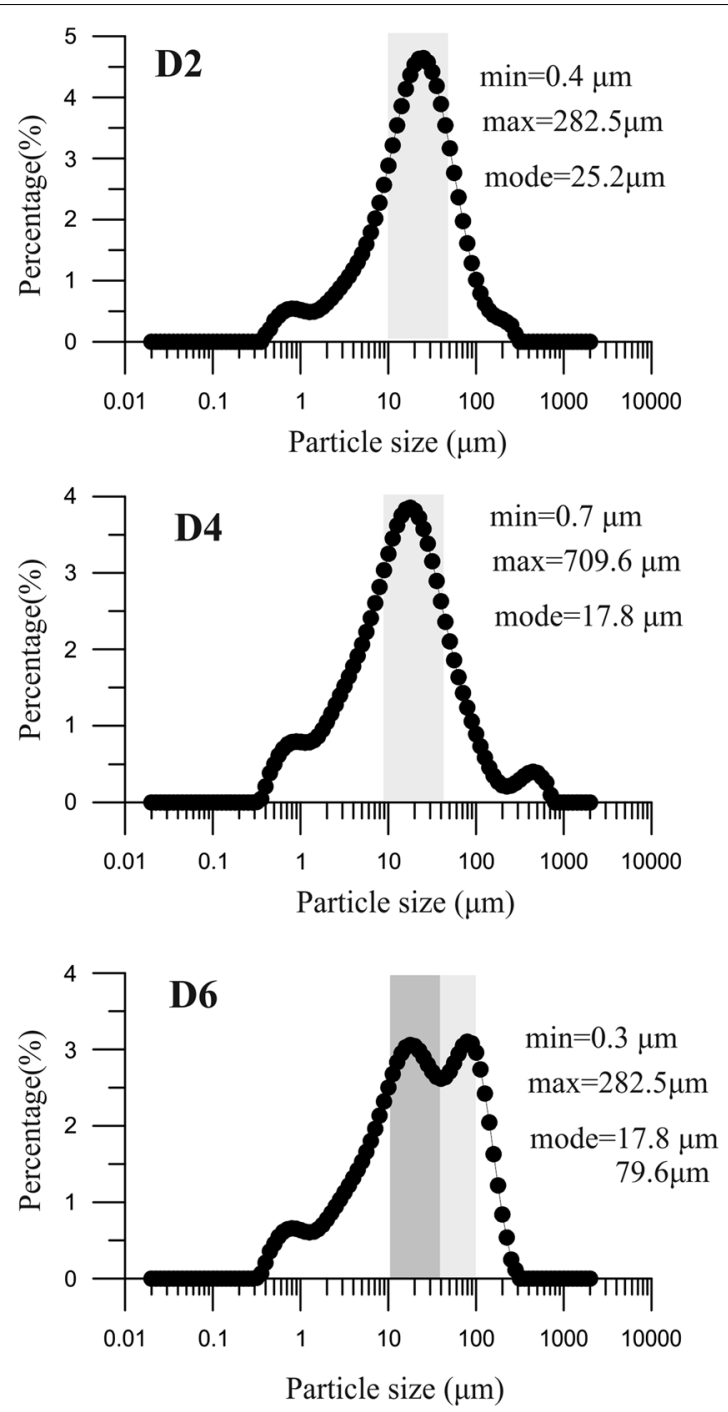

Fig. 3 Particle size distribution of the atmospheric dust samples (D1-D6) from Ebinur region

which induce the middle latitude jet stream to blow more strongly; westerly winds become stronger than normal over the northern Eurasian Continent (Sun et al. 2001). The strong westerly jet in the upper troposphere is linked to the development of cyclones and frontogenesis at low levels that can cause strong winds and provided the dynamic factor for the increase dust storm in central Asia and Xinjiang.

In order to distinguish the dynamic condition controlled the aeolian dust transport, we calculated the correlation coefficient between the $\mathrm{AO}$ index, and $\mathrm{C} 2$ contents reflected the intensity of aeolian transport. Due to the differences in time resolution between the
$\mathrm{AO}$ index and $\mathrm{C} 2$ contents, the average data were also recalculated with 5-year intervals. There was not correlation between $\mathrm{AO}$ index and $\mathrm{C} 2$ contents from 1875 to $2010(\mathrm{r}=0.251, \mathrm{~N}=28$ ); however, the AO index has a remarkable correlation to $\mathrm{C} 2$ contents from 1875 to 1950 $(\mathrm{r}=0.615, \mathrm{~N}=16, \mathrm{p}<0.05)$. Based on the above analysis, climate was dry around 1910s-1930s in this region associated with the appropriate dynamic condition, which provided the enhanced source materials and wind power for the aeolian dust transport. Since 1950s, the climate controlled the foundation of aeolian dust transport, and the aeolian dust transport won't be increased under the humid climate. 

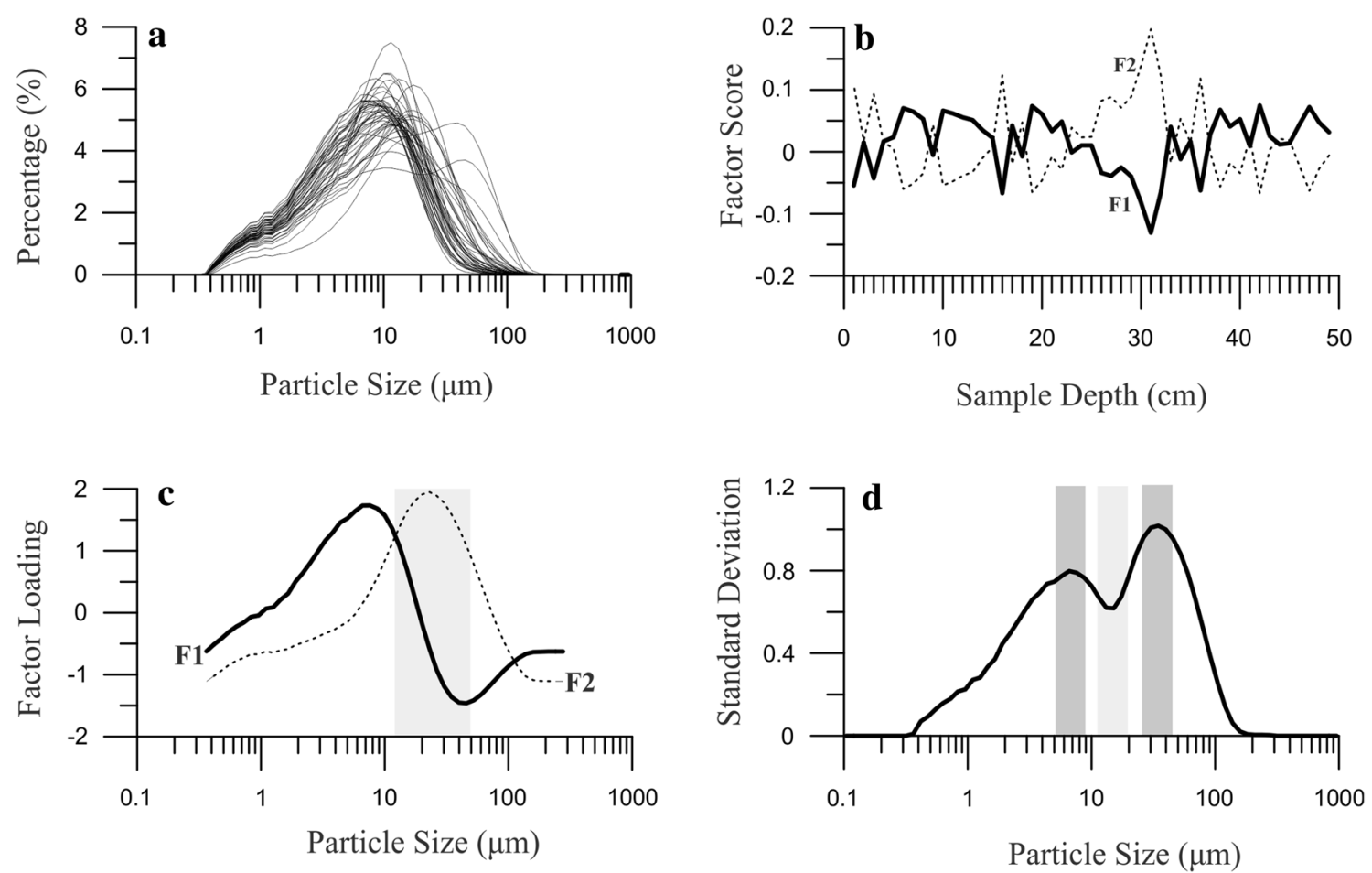

Fig. 4 The particle size distribution of Ebinur Lake sediments (a), the factor score (b) with their factor loading coefficients (c) from factor analysis, and the standard deviation values versus particle size of sediment core AB01 (d)

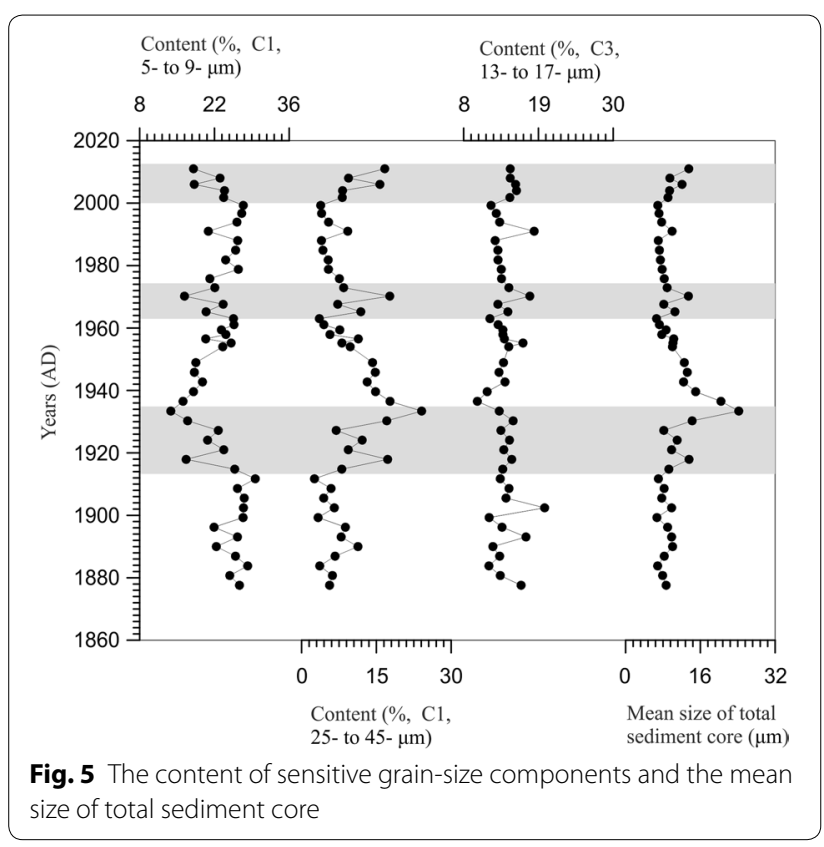

\section{Conclusions}

Lakes in arid areas received materials from runoff and conveyed by wind. Mathematics can be used in important ways to apply data during the in-depth study of environmental information related to sediment grain-size data when combined with instrumental records and historical documents.

With comparison of natural dust samples, the coarser particle fraction of the Ebinur Lake core sediments was mainly from aeolian transport of drainage surface sediments. The content of the 25-45- $\mu \mathrm{m}$ size class represents a component with the highest changing frequency and the coarse particle-size population mainly influences the entire variation of the sedimentary sequence.

During the last 150 years, the sediments contain significant amounts of aeolian dust and low amounts of riverine particles during the periods of 1915-1935 and 1965-1975, and since the beginning of the 2000s. The climate was dry around 1910s-1930s in this region associated with the appropriate dynamic condition, which 

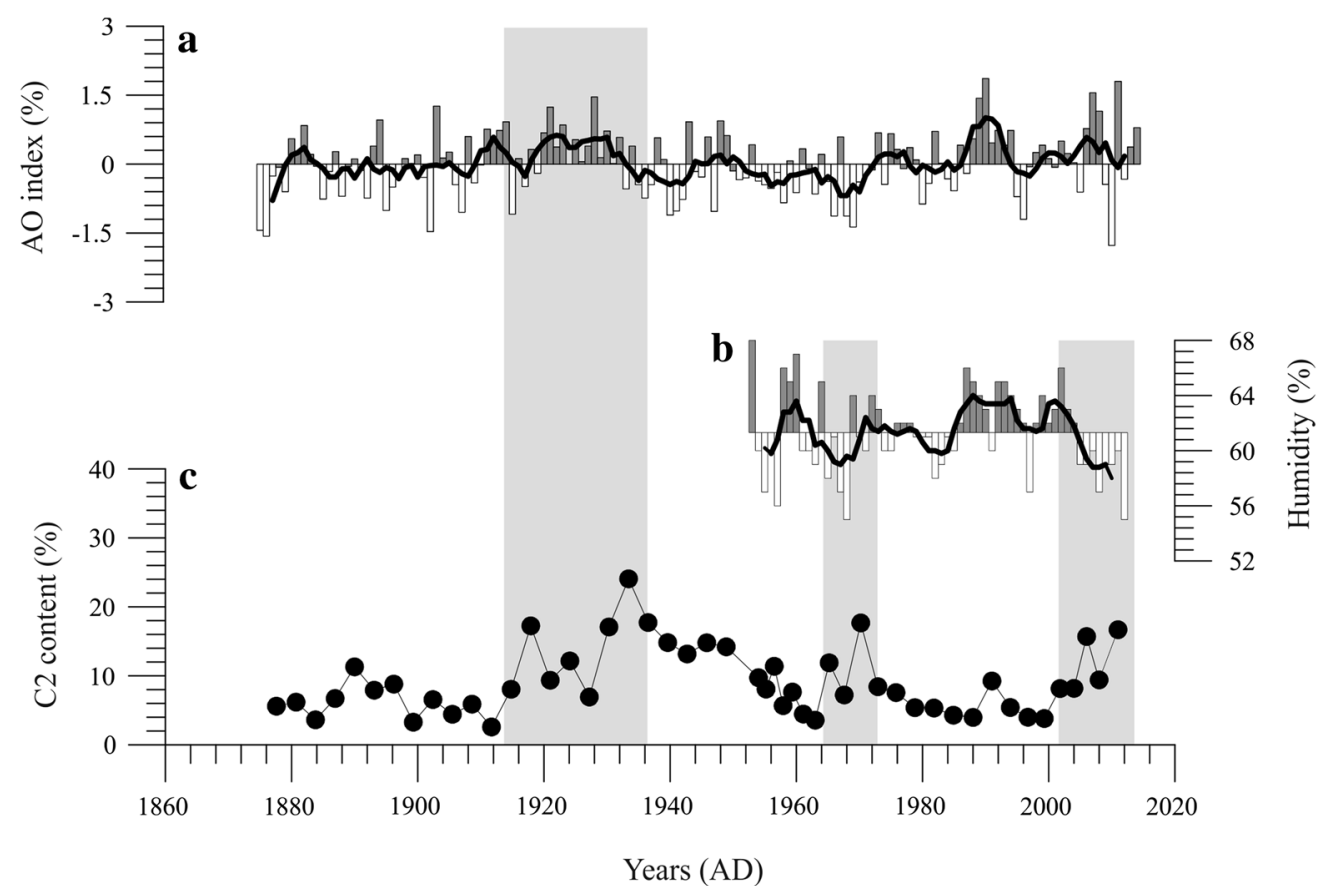

Fig. 6 a The Arctic Oscillation index (Li and Wang, 2003) with five-running average. b The relative humidity in Jinghe with five-running average. c Aeolian environmental variation in Ebinur Lake inferred from the C2 contents

provided the enhanced source materials and wind power for the aeolian dust transport. Since 1950s, the climate controlled the foundation of aeolian dust transport, and the aeolian dust transport won't be increased under the humid climate.

\section{Authors' contributions}

JW designed the study; LM and JA carried out experimental analysis; LM and JA analyzed the data; LM and JW wrote the manuscript. All authors read and approved the final manuscript.

\section{Author details}

${ }^{1}$ State Key Laboratory of Desert and Oasis Ecology, Xinjiang Institute of Ecology and Geography, Chinese Academy of Sciences, Urumqi 830011, China.

2 State Key Laboratory of Lake Science and Environment, Nanjing Institute of Geography and Limnology, Chinese Academy of Sciences, Nanjing 210008, China.

\section{Acknowledgements}

The National Natural Science Foundation of China (41471173; 41471098) and the Youth Innovation Promotion Association CAS supported this study.

\section{Competing interests}

The authors declare that they have no competing interests.

Received: 27 November 2015 Accepted: 12 April 2016

Published online: 19 April 2016

\section{References}

Anderson NJ (1995) Using the past to predict the future: lake sediments and the modelling of limnological disturbance. Ecol Model 78:149-172
Appleby P (2001) Chronostratigraphic techniques in recent sediments. In: Last WM, Smol JP (eds) Tracking environmental change using lake sediments volume 1: basin analysis, coring, and chronological techniques. Kluwer Academic Publishers, Dordrecht, pp 171-203

Boulay S, Colin C, Trentesaux A, Pluquet F, Bertaux J, Blamart D, Buehring C, Wang P (2003) Mineralogy and sedimentology of Pleistocene sediment in the South China Sea (ODP Site 1144). In: Proceedings of the ocean drilling program, scientific results, pp 1-21

Chen F, Huang X, Zhang J, Holmes JA, Chen J (2006) Humid Little Ice Age in arid central Asia documented by Bosten Lake, Xinjiang, China. Sci China Ser D 49:1280-1290

Christensen ER, Bzdusek PA (2005) PAHs in sediments of the Black River and the Ashtabula River, Ohio: source apportionment by factor analysis. Water Res 39:511-524

D’Arrigo R et al (2005) A reconstructed Siberian High index since A.D. 1599 from Eurasian and North American tree rings. Geophys Res Lett 32:1-4

Hurrell JW, Kushnir Y, Visbeck M, Ottersen G (2003) An overview of the North Atlantic Oscillation. In: Hurrell JW, Kushnir Y, Ottersen G, Visbeck M (eds) The North Atlantic Oscillation, climatic significance and environmental impact, vol 134. AGU Geophysical Monograph, Washington, DC, pp $1-35$

Jeong J-H, Ou T, Linderholm HW, Kim B-M, Kim S-J, Kug J-S, Chen D (2011) Recent recovery of the Siberian High intensity. J Geophys Res 116:D23102. doi:10.1029/2011JD015904

Last WM, Smol JP (2006) Tracking environmental change using lake sediments: volume 2: physical and geochemical methods, vol 2. Kluwer Academic Publishers, Dordrecht

Lawrence CR, Neff JC (2009) The contemporary physical and chemical flux of aeolian dust: a synthesis of direct measurements of dust deposition. Chem Geol 267:46-63

Li J, Wang J (2003) A modified zonal index and its physical sense. Geophys Res Lett 30:1632. doi:10.1029/2003GL017441

Li J, Gou X, Cook ER, Chen F (2006) Tree-ring based drought reconstruction for the central Tien Shan area in northwest China. Geophys Res Lett 33:L07715. doi:10.1029/2006GL025803 
Li B, Chen Y, Shi X (2012a) Why does the temperature rise faster in the arid region of northwest China? J Geophys Res 117:D16115. doi:10.1029/201 2JD017953

Li L, Li C, Song J (2012b) Arctic Oscillation anomaly in winter 2009/2010 and its impacts on weather and climate. Sci China Earth Sci 55:567-579

Liang E et al (2006) The 1920s drought recorded by tree rings and historical documents in the semi-arid and arid areas of northern China. Clim Change 79:403-432

Liu X, Yin Z-Y, Zhang X, Yang X (2004) Analyses of the spring dust storm frequency of northern China in relation to antecedent and concurrent wind, precipitation, vegetation, and soil moisture conditions. J Geophys Res 109:D16210. doi:10.1029/2004JD004615

Liu D, Abuduwaili J, Lei J, Wu G (2011) Deposition rate and chemical composition of the aeolian dust from a bare saline playa, Ebinur Lake, Xinjiang China. Water Air Soil Pollut 218:175-184

Ma L, Wu J, Abuduwaili J (2013) Climate and environmental changes over the past 150 years inferred from the sediments of Chaiwopu Lake, central Tianshan Mountains, northwest China. Int J Earth Sci 102:959-967

McTainsh G, Strong C (2007) The role of aeolian dust in ecosystems. Geomorphology 89:39-54

Neff JC, Ballantyne AP, Farmer GL, Mahowald NM, Conroy JL, Landry CC, Overpeck JT, Painter TH, Lawrence CR, Reynolds RL (2008) Increasing eolian dust deposition in the western United States linked to human activity. Nat Geosci 1:189-195

Overpeck J et al (1997) Arctic environmental change of the last four centuries. Science 278:1251-1256

Peng Y, Xiao J, Nakamura T, Liu B, Inouchi Y (2005) Holocene East Asian monsoonal precipitation pattern revealed by grain-size distribution of core sediments of Daihai Lake in Inner Mongolia of north-central China. Earth Planet Sci Lett 233:467-479

Pennington W, Tutin T, Cambray R, Fisher E (1973) Observations on lake sediments using fallout 137Cs as a tracer. Nature 242:324-326

Qiang M, Chen F, Zhang J, Zu R, Jin M, Zhou A, Xiao S (2007) Grain size in sediments from Lake Sugan: a possible linkage to dust storm events at the northern margin of the Qinghai-Tibetan Plateau. Environ Geol 51:1229-1238

Qin X, Cai B, Liu T (2005) Loess record of the aerodynamic environment in the east Asia monsoon area since 60,000 years before present. J Geophys Res 110:B01204. doi:10.1029/2004JB003131
Sofowote UM, McCarry BE, Marvin CH (2008) Source apportionment of PAH in Hamilton Harbour suspended sediments: comparison of two factor analysis methods. Environ Sci Technol 42:6007-6014

Sun J, Zhang M, Liu T (2001) Spatial and temporal characteristics of dust storms in China and its surrounding regions, 1960-1999: relations to source area and climate. J Geophys Res 106:10325-10333. doi:10.1029/2 000JD900665

Sun D, Bloemendal J, Rea D, Vandenberghe J, Jiang F, An Z, Su R (2002) Grain-size distribution function of polymodal sediments in hydraulic and aeolian environments, and numerical partitioning of the sedimentary components. Sediment Geol 152:263-277

Sun Y, Gao S, Li J (2003) Preliminary analysis of grain-size populations with environmentally sensitive terrigenous components in marginal sea setting. China Sci Bull 48:184-187

Wake C, Mayewski P, Li Z, Han J, Qin D (1994) Modern eolian dust deposition in central Asia. Tellus B 46:220-233

Wang X, Dong Z, Zhang J, Liu L (2004) Modern dust storms in China: an overview. J Arid Environ 58:559-574

Wang X, Zhou Z, Dong Z (2006) Control of dust emissions by geomorphic conditions, wind environments and land use in northern China: an examination based on dust storm frequency from 1960 to 2003. Geomorphology 81:292-308

Weltje GJ (1997) End-member modeling of compositional data: numericalstatistical algorithms for solving the explicit mixing problem. Math Geol 29:503-549

Wu J, Yu Z, Wang N (2009) Possible solar forcing of 400-year wet-dry climate cycles in northwestern China. Clim Change 96:473-482

Xiao J, Chang Z, Si B, Qin X, Itoh S, Lomtatidze Z (2009) Partitioning of the grain-size components of Dali Lake core sediments: evidence for lakelevel changes during the Holocene. J Paleolimnol 42:249-260

Xu X, Levy JK, Zhaohui L, Hong C (2006) An investigation of sand-dust storm events and land surface characteristics in China using NOAA NDVI data. Glob Planet Change 52:182-196

Zhang K, Qu J, Zu R, Fang H (2005) Temporal variations of sandstorms in Minqin oasis during 1954-2000. Environ Geol 49:332-338

Zhong W, Xue J, Zheng Y, Ma Q, Cai Y, Ouyang J, Xu L, Zhou S, Yu X (2010) Variations of monsoonal precipitation over the last 16,000 years in the eastern Nanling Mountains, South China. J Paleolimnol 44:177-188

\section{Submit your manuscript to a SpringerOpen ${ }^{\circ}$ journal and benefit from:}

- Convenient online submission

- Rigorous peer review

- Immediate publication on acceptance

- Open access: articles freely available online

- High visibility within the field

- Retaining the copyright to your article

Submit your next manuscript at springeropen.com 